\title{
GRZEGORZ EMBROS
}

Institute of Ecology and Bioethics, Cardinal Stefan Wyszyński University, Warsaw

\section{Role of procedures in environmental management system}

Słowa kluczowe: ochrona środowiska, systemy zarządzania środowiskowego, procedury

Key words: environmental protection, environmental management systems, procedures

\section{Summary}

In the paper, the author attempts to point out the meaning of procedures for the environmental management system (EMS). Particular attention is paid to form and content as well as to the functions, proprieties and structure of the procedures. The analyses were carried out taking into account a systemic approach of the essential topics to the ISO 14001 standard. Based on the chosen procedure, some fundamental methods of elaborating upon and implementing the EMS procedures were outlined. It was also presented that procedures written in accordance with these rules might provide vital support to the improvement of the organization's management systems and might optimize the processes in the areas they cover.

\section{Introduction}

Nowadays, environmental protection in an organization cannot be based solely on adapting to valid legal requirements. Issues related to the environmental protection such as: waste management, emissions of 
pollutants or energy efficiency are of high importance to organizations (e.g. high cost of functioning, possibility of losing environmental permits etc.) This requires an appropriate approach towards the issues, adequate to their rank and scale.

All elements of an organization's activity shall undergo continuous analyses and environmental risk assessment against their social and natural environmental impact. The achievement postulates become possible due to implementation of an environmental management system based on either one of the international ISO 14000 standards or Environmental Management and Auditing System regulation (EMAS) (Official Journal EU L 342/1 PL, 2009; Grobe 2005: 129182). It significantly enables an organization to attain some economic advantages (e.g. optimization of resources use), to improve the processes carried out in an organization and to produce the products that live up to the expectations of the most demanding customers (Brauweiler J., Helling K., Kramer 2005: 113-128).

According to the ISO 14001:2004 standard, the environmental management system (EMS) should be an integrated part of an organization's management system. The standard recommendation is, that all basic EMS parts such as: an organizational structure, planning responsibilities, practices, procedures and means enabling realization of environmental policy assumptions should be consistent with other organization's functions and its development strategy. (PN-EN ISO 14001, 2004: No. A. 3.8). The management system built up in accordance with the standard requirements, allows for continuous improvement of all the processes encompassed by the system. Consequently, it results in achieving better environmental performance.

The organization, that plans to implement environmental management system needs to begin with a complex environmental review (basic review) including all the organization's activities, its products and services. Such a review helps to identify the environmental aspects (all elements of organization's activities, products or services that can interact with the environment) (PN-EN ISO 14001, 2005: 
No. A. 3.6) and legal requirements for the processes as well as all the incidents or emergency situations that have taken place within the processes.

In identifying the environmental aspects, it is necessary to define and assess their environmental impact (e.g. types and quantities of substances emitted into the environment). The identification process should include normal activity conditions, start-ups and shut-downs of installations as well as the potential environmental impact of the emergency situations. The abovementioned review enables the description of an organization's position in relation to legal requirements and good environmental practices. Accurately carried out, the review helps prepare adequate system documentation including procedures. The EMS procedures are to complement documentation functioning within other management systems present in an organization. For not only should they improve environmental performance, but also the general organization and management,

Thanks to cooperation with the environmental department of one of the biggest production plants in the Mazowsze area (food sector), the author of this paper has the possibility to participate in the preparation of the EMS procedures and the collection of information on the system once implemented.. He gains insight into the process of procedures testing in practice. Subsequently, it allows for access to some valuable information on key aspects associated to procedures use in relation to the concrete processes and the possibility to analyze their place and meaning for the certified Environmental System Management functioning.

The interviews carried out with the environmental specialists employed in the above mentioned enterprise, revealed some interesting issues related to the manner in which the procedures are prepared, implemented and used. They relate, in particular, to the content (e.g. a lot of unnecessary information or missing information crucial to properly carrying out the actions), the structure and even the way a procedure's text is formatted (what influences its readability), a number 
of the EMS procedures, the method of their distribution, the analysis of causes for which the procedures are not applied by the employees etc. The mentioned problems, especially when accumulated, might cause a procedural disturbance. Admittedly, the system might function in the presence of the faultily constructed procedures, however, it hinders the process of achieving environmental targets (postulated in the organization environmental policy) and makes it impossible to further improve the system.

It is to be noted here that the Environmental Management System cannot be equipped in any procedures, but the procedures should be adequate to defined targets, tasks and aspects of the organization. The principal aim of the paper is to point out and underline the role of a procedure as one of the EMS improvement tools. In order to demonstrate best practice in this area, the author presents a properly constructed EMS procedure, functioning within a certified system.

\section{Features and functions of a procedure}

A procedure is, according to ISO 14001:2004 standard, a specified way to carry out an activity or a process (PN-EN ISO 14001, 2005: No. A. 3.19). Whether a procedure is documented or not, still, the final effect of its application counts.

The main role of a procedure is to improve a way of proceeding in a specific process. Therefore, a procedure shall reflect the conditions of a factual process. Otherwise, it does not meet its primary aim of improving management process. As Andrzej Blikle described in his publication „A Quality Doctrine” - „Procedures are a basic element in the realization of a continuous improvement rule. They need to be written together with the interested parties or even solely by them. It is necessary to explain that the presence of procedures is not in contradiction to the free choice rule. One cannot breach the procedures but it is possible and required to change them whenever we see the possibility of their improvement. That is what continuous management is about." (Blikle 2013: 112). 
It is to be underlined, that documented procedures fulfill their aim only if they are written in a clear and readable way and a method of proceeding described in a document is comprehensible to people who are to use them at work. A procedure shall contain a well-defined aim to present some added value gained to an organization through its implementation. The responsibilities should be described in an unequivocal manner, so as not to cast any doubts.

A. Blikle defines some quality criteria which need to be fulfilled by a well-constructed procedure: „We may say that a document meets a documentation quality standard when:

1. it is substantially correct:

- its content is not untrue;

- it fully covers a subject;

- it is not contrary to the generally accepted standards and legal regulations;

- it is not contrary to the internal company standards;

- it does not breach the generally accepted social communication and conduct standards;

2. it is communicatively correct:

- it is comprehensible for the interested parties;

- its content is unequivocal and internally consistent (...)

3. it is correct as to the form:

- lingual (spelling, punctuation, grammar, style, vocabulary, appropriateness);

- editorial layout;

- typographic layout (a font size and shape, spaces, distinctions)."

Such a procedure makes the so called intellectual tool as indispensable at performing professional activities as a material tool e.g. flowmeter (Blikle 2013: 154-155).

A procedure as a document undergoing changes being a result of improvements implemented in an organization, requires a suitable method of management to guarantee fulfilment of the following conditions: 
- availability at the work station, which it concerns;

- upgrading process ensuring that there aren't two different updates of the same procedure at the same time;

- a form standardization to facilitate supervision and usage (Blikle 2013: 186).

To attain the above described state of affairs it is necessary to establish and implement a well-constructed procedure of Documents and Records Control. The number of procedures in the environmental protection management may differ depending on the type of organization. An industrial plant will probably operate on more documents than a national authority office, however, they should always be adequate for the conducted activity.

An improperly prepared procedure will never fulfill its task and will be perceived by employees as a useless pile of paper. A correctlywritten document, living up to the above mentioned criteria shall be of assistance to all employees both present and future. It shall improve activities and increase efficiency. It should not hamper the realization of postulated goals.

\section{Environmental management system procedures}

Environmental performance systematization in an organization based on one of the international standards e.g. ISO 14001:2004, necessitates establishing and implementing some extra documents. Besides documented policy, objectives, targets and programmes, an organization shall describe a scope of the environmental management system and its main elements (The Book of the Environmental Management System). It should also establish, implement and maintain procedures required by the standard. One of the more important procedures required by the standard is, for example, a procedure of identification and assessment of the environmental aspects related to the organization's activities. Of particular importance is, in case of the 
mentioned procedure, determining criteria to identify those aspects, which have or could have significant impact on the environment and are of significant environmental threat. The environmental risk, being the function of the probability of the occurrence of environmental damage and its strength, is much higher in such aspects and it may require the establishment of some extra procedures, standards, instructions etc. to reduce the risk (IEMA 2006:11-24).

The EMS documentation can be divided into three levels:

- environmental policy, objectives, system description - a strategic level

- procedures, environmental targets - tactical level

- instructions, records - operation level

The extent of the EMS documentation may differ across different organizations, depending on:

- the size and type of organization and its activities;

- the complexity of processes and their interactions;

- the competence of personnel (Matuszak-Flejszman 2007:105 ).

Below is presented the content, structure and form of an exemplary procedure that is required by the ISO 14001:2004 standard (PN-EN ISO 14001, 2005: No. A. 4.3.1). It is the procedure of the identification of environmental aspects related to an organization's activities, its products and services functioning in the environmental management system implemented in one of the Mazowsze area's biggest food industry plants.

A procedure shall contain a properly framed title, which defines the procedure's content in a concise and precise manner. In the analyzed case it is the "Procedure of Identification and Assessment of Environmental Aspects". There is an issue date, which at the same time constitutes a specific document identification signature. Next, there is the name of a person (or a group of people) who has developed the procedure.

One of the vital things is a proper definition that is adequate to its application and aim. In this case, the aim of the procedure is to present 
the way of carrying out the identification of the environmental aspects and the assessment process in the organization. It is also possible to define the scope of its application, if the EMS is not applicable to all activities of the organization.

A procedure is also to contain some definitions if it is necessary for the proper realization of its aim. The identification of environmental aspects and the assessment process shall enclose the definitions of the most important terms: an environmental aspect (the element of an organization's activities or products or services that can interact with the environment) or an environmental impact (any change to the environment whether adverse or beneficial, wholly or partially resulting from an organization's activities its products and services) (PN-EN ISO 14001, 2005: No. A. 3.6-3.7).

In case there are some external documents that the procedure is based on, or records required by the procedure, it is necessary to refer to them in the procedure e.g. Environmental Aspects Assessment Spreadsheet - the record containing all the aspects of the assessment and allowing for the pointing out of significant environmental aspects. In this concrete procedure one of the records is also the Environmental Management Spreadsheet. It contains some extra requirements and working guidelines for significant environmental aspect management. Defining responsibilities in the area encompassed by the procedural requirements, one needs to take into account whether they have been described beforehand in, for example, the Book of Environmental Management System, or a document containing description of all EMS elements. If the answer is positive it is enough to include such information in the procedure. Otherwise, it is necessary to define and describe responsibilities in the very procedure.

Having filled in the abovementioned information, it is likely to go to the description of the specified way a process is carried out. It shall be as exact as possible and unequivocal. In case of the analyzed procedure, it is a description of the identification of environmental aspects and assessment method. It is reasonable to shortly characterize 
the methodology of the identification and assessment, including the necessity of taking into account different functioning conditions (normal, abnormal and emergency) and current legal and other requirements for the specific aspects. Some recommendations may be formulated e.g. to carry out the identification of environmental aspects and assessment by a site visit and/or discussion of people responsible for the specific organization's area. In case there are any extra tools used in the described process, it is necessary to include information about them in the procedure e.g. Environmental Aspects Assessment Spreadsheet or Risk Score method for the appraisal of aspects and evaluation of environmental risk related to each aspect.

After having defined the process methodology, it is necessary to describe how the environmental aspects are assessed. The appraisal process includes: an aspect's environmental impact, the impact direction- water, soil, air, people; category of activity- normal, abnormal, emergency; likelihood of legal and other infringements.

In the appraisal of aspects, it is vital to assess the significance of environmental impact. Therefore, it is important to properly define the level of such an impact by an adequate evaluation (value I) - for each environmental aspect and for each environmental aspect's impact. It may be assigned a numerical value in accordance with an adapted scale (Risk Score) e.g.:

Table 1. Environmental impact significance assessment

\begin{tabular}{|c|c|}
\hline Value I & Description \\
\hline 10 & Very strong \\
\hline 6 & Strong \\
\hline 3 & Moderate \\
\hline 1 & Weak \\
\hline 0,5 & Very weak \\
\hline 0,2 & Minute \\
\hline
\end{tabular}


The obtained values enable relatively simple numerical treatment with use of, for example, a calculation spread sheet. Each of the described levels needs to be respectively defined.

Very strong a multi-direction impact that may result in significant environmental damage, exceeding the plant borders; there is a possibility of breaching emission limit values;

Strong impact on at least 2 environmental elements that may result in environmental damage, exceeding the plant borders, there is a possibility of breaching emission limit values;

Moderate impact on at least 1 environmental element, there is no possibility of breaching any emission limit values, low risk of environmental damage, exceeding the plant borders;

Weak a multi-directional impact, enclosed within the plant borders, with very low risk of environmental damage;

Very weak impact on 1,2 environmental elements, enclosed within the plant borders,

Minute possible but negligible.

The next obligatory element is the adequate assessment of the environmental impact of the aspects, which needs to be taken into account and placed in the discussed procedure as a frequency of impact occurrence (F). It indicates how often a specific environmental impact takes place and it may be defined with use of the scale presented below:

Table 2. Frequency of an impact occurrence evaluation

\begin{tabular}{|c|l|}
\hline Value F & \multicolumn{1}{|c|}{ Description } \\
\hline 10 & Constant \\
\hline 6 & Often (every day) \\
\hline 3 & Rare (once a week) \\
\hline 2 & Occasional (once a month) \\
\hline 1 & Minimal (several times per annum) \\
\hline 0,5 & Minute (once per annum or less) \\
\hline
\end{tabular}


While assessing environmental aspects, it is recommended to include potential financial losses related to the environmental impact of the aspects if it is not properly supervised and managed. Financial losses (L) may be defined with use of the following scale:

Table 3. Financial losses evaluations

\begin{tabular}{|c|l|}
\hline Value L & \multicolumn{1}{|c|}{ Description } \\
\hline 1 & $<500 \mathrm{zł}$ PLN \\
\hline 3 & $<500$ PLN $>1000$ PLN \\
\hline 7 & $1001>10000$ PLN \\
\hline 15 & $10001>100000$ PLN \\
\hline 40 & 100000 do 1000 000 PLN \\
\hline 100 & $>1000000$ PLN \\
\hline
\end{tabular}

At this stage it is possible to summarize the environmental aspect assessment. It is carried out by expressing a risk level of an aspect as a product of numerical parameters I, F,L. The final risk assessment is classified, depending on the number, to one of the following categories:

Tabel 4. Risk level evaluation

\begin{tabular}{|c|c|}
\hline Risk Value & Assessment \\
\hline$<70$ & Low \\
\hline $71-150$ & Medium \\
\hline$>151$ & High \\
\hline
\end{tabular}

In the final phase of the assessment, one may define the specific „critical” options for the obtained results. In the analyzed case, an essential risk acceptance criterion is a fulfillment of legal requirements. Regardless of the final risk assessment, the probability of legal transgression results in the implicit impact classification of "significant". Each environmental aspect, with at least one significant impact, should be classified as "significant". In cases, where there is no risk of legal or regulatory breach, a numerical evaluation becomes the final impact 
assessment. The identification of environmental aspects and assessment procedures shall contain relevant records describing an approach towards compliance with the rules.

Such records assist in properly and adequately interpreting the assessment results. The "significant" status of an aspect means that its environmental impact is high enough to increase the probability of environmental damage and hence the aspect needs to be strictly supervised, for example by more frequent environmental internal audits and inspections, more frequent emission monitoring, some extra procedures or instructions improving operational control in the area, more frequent training increasing competencies of persons working in the area. To better manage such an aspect and work out an efficient improvement plan, it is recommended that a document be prepared collecting all the managing means appropriate to the aspect. In the analyzed case it is the Environmental Management Spreadsheet for each aspect with identified significant environmental impact. This document is available at work stations in the aspect's area and it is used for the purposes of training both permanent and seasonal employees. Such an approach may result in optimization of process and decreasing of environmental risk, which means that the system keeps improving.

In the context of continuous improvement (recurring process of enhancing the environmental management system in order to achieve improvements in overall environmental performance consistent with the organization's environmental policy) (PN-EN ISO 14001, 2005: No. A. 3.2), it is crucial to keep the aspect's assessment up to date. The procedure shall contain a relevant record to remind people responsible for the process to carry out the periodic aspect reviews (e.g. once a year). The environmental aspects should also be reviewed and reassessed (if there is such a need) after the occurrence of an emergency situation, changes in legal and other requirements, or technical changes in installations located in the aspect's area. The review and reassessment may be carried out only in the areas where the abovementioned situations have taken place. 
Such a constructed procedure containing the discussed elements shall effectively fulfill its aims. It should be remembered that all the procedures functioning within the EMS system, like any other organization's system documentation, need to be changed along with the changes in the organization. The procedures cannot be properly used or fulfill their aims, while the organization undergoes changes and develops and there is no reflection of the changes in the procedures. Thus, systemic documentation control in the organization is a must.

Quality and quantity of the EMS procedures is one of the factors influencing the improvement of system, its efficiency and effectiveness (Matuszak-Flejszman 2010: 107-108). The research carried out by the International Standardization Organization (ISO) indicates, that one of the EMS weaknesses, resulting in low system efficiency, is the difficulty associated with the large amount of work in maintaining the system documentation. (Matuszak-Flejszman 2010: 113). One of the reasons might be the extended documentation of the system, containing information, which one can find, for example, in legal acts, standards or administrative decisions. Such documentation does not improve the way of proceeding along a concrete process and merely "functions" in the environmental management system. Consequently, it increases workload related to supervision of the system documentation.

The other reason might be a poorly designed documentation control system. According to the ISO 14001:2004 standard recommendation, an organization should establish, implement and maintain a procedure(s) for the identification, storage, protection, retrieval, retention and disposal of records (PN-EN ISO 14001, 2005: No. A. 4.5.4). In case the documents and records need to be accepted by many people, the documents' distribution and archiving is based on hard copies and electronic documents are not recognized, such a system undoubtedly generates significant administrative burden. In large organizations it requires the employment of an extra person or people to fulfil all the requirements imposed upon the organization by the organization itself. 
It is to be underlined that the ISO 14001:2004 standard does not define how to carry out the documentation control process.

\section{Conclusion}

The activities related to environmental protection, implemented in organizations of various types, are not only to solve cognitive issues (theoretical). Above all, due to the organization's environmental aspects impact (often significant) they are focused on solving the decision-making problems (practical). In order to properly, correctly and adequately address both these groups of problems, it is necessary to acquire knowledge and skills enabling decision-making to solve specific issues with the use of sufficient realization means.

In order to manage the environmental performance as efficiently as possible, organizations implement a systemic approach in the management system. Such a method enables the covering of a full range of issues. In the management praxis, not only is the economic factor included but also human and natural capital (Piontek 2007: 55-62). Taking into account the abovementioned perspective, the management method should entail stable and sustainable development (Borys 2005: 47, 80). Bazyli Poskrobko claims that „pursuing the sustainability and stability of development should take place at each level of the organization structure: from global system, across international and national systems to the local ones, form sectorial systems to individual enterprises" (Poskrobko 2007: 25). Therefore, one can say that a properly functioning environmental management system (next to the quality or safety management systems) is a tool for the implementation of the stable and sustainable development idea in the management process.

The above mentioned relationships become specific throughout much more detailed guidelines contained in the ISO 14001:2004 standard concerning construction, implementation, maintenance and improvement of the environmental management system in the organization. From this perspective, there is a need for developing 
some tools to deal with actual issues. Often, these tools are created and dedicated to specific environmental problems that the organization struggles with. An example of such specific, dedicated and practical tools are procedures.

Application of procedures is to facilitate and improve the work of those involved in a specific organization's activity. The procedures are a source of knowledge in the area to which they relate. In a specific and orderly manner they standardize the way of proceeding in a concrete situation. Being a tool contributing to the environmental system management improvement and optimization, the procedures, at the same time, provide management support for the activities they pertain to. Subsequently, they become a tool practically contributing to the prevention of neglect and errors, which may occur at different stages of the realization process. However, it is to be stressed, that the above is only possible if the procedures are appropriate to the form, substance and in accordance with good practices applied in the area in question.

\section{Bibliography}

Blikle A., 2013, Doktryna jakości, Warszawa.

Borys T. (red.), 2005, Wskaźniki zrównoważonego rozwoju,Wyd. Ekonomia i środowisko, Warszawa-Białystok.

Brauweiler J., Helling K., Kramer M., 2005, Koncepcje kompleksowego zarzq̨dzania środowiskiem, w: Kramer M., Brauweiler J., Nowak Z. (red.), Międzynarodowe zarządzanie środowiskiemt, Wyd. C.H. Beck, Warszawa, 113-128.

Grobe H., 2005, Wymagania systemów zarządzania środowiskowego wg rozporzadzenia EMAS i normy ISO 14001, w: Kramer M., Brauweiler J., Nowak Z. (red.), Międzynarodowe zarządzanie środowiskiem, Wyd. C.H. Beck, Warszawa, 129-182.

IEMA, Risk Management for the Environmental Practitioner, Best Practice Series, Vol. 7, 2006. 
Matuszak-Flejszman A., 2007, System Zarządzania Środowiskowego $w$ organizacji, Wyd. Akademii Ekonomicznej w Poznaniu, Poznań.

Matuszak-Flejszman A., 2010, Determinanty doskonalenia systemu zarządzania środowiskowego zgodnego z wymaganiami normy ISO 14001, Wyd. Uniwersytetu Ekonomicznego w Poznaniu, Poznań.

Official Journal EU, L 342/1 PL, 22.12.2009, Annex II- Environmental management system requirements and additional issues to be addressed by organisations implementing EMAS, pkt. A.3.1. Environmental Aspects.

Piontek F., 2007, Teoria rozwoju a personalistyczna koncepcja teorii ekonomicznej, w: Piontek B., Piontek F. (red.), Zarządzanie rozwojem. Aspekty społeczne, ekonomiczne i ekologiczne, Wyd. PWE, Warszawa, 55-62.

PN-EN ISO 14001, 2005, Environmental Management Systems Requirements with Guidance for Use, Warszawa.

Poskrobko B. (red.), 2007, Zarządzanie środowiskiem, Wyd. PWE, Warszawa. 